\title{
Pedagogit barrikadeille!
}

Peter McLaren (2000). Che, Freire ja vallankumouksen pedagogiikka. Like 2009, 319 s.

\section{$\mathrm{H}$}

arvoin on ollut niin hankalaa aloittaa kirjasta kirjoittaminen kuin nyt. Harvoin on myöskään kirjan lukeminen ollut yhtä työlästä kuin nyt. Tämä kaikki siitä huolimatta, että kirjan nimihenkilöt Che Guevara ja Paolo Freire herättävät minussa tietenkin vanhan marxilaisen vallankumouksellisen. Ja kun sanon marxilainen, en sano Lenin. Enkä sano Stalin. Tämä on suomalaisessa keskusteluilmastossa syytä selkeästi todeta. Valitettavasti vieläkin.

Kirjoittaja Peter McLaren kuuluu kotisivujensa perusteella samaan kategoriaan ja sukupolveen kanssani. Hän on kolme viikkoa minua vanhempi. Meillä on ilmeisesti myös sama vallankumous(romanttinen) vuoden 1968 kokemus. Minä olin silloin Pariisissa, en tiedä missä McLaren oli.

Kirja vaikuttaa suurelta osalta suorastaan anakronistiselta, paluulta vuoden 1968 ajattelun maailmaan. Siihen aikaan myös Che oli kova sana, Freire oli vasta julkaissut ensimmäisen kirjansa Educacão como Práctica de Liberdade (1967, Kasvatus vapauden käytäntönä, ei suomennettu). Jo seuraavana vuosikymmenenä Freirestä puhuttiin meilläkin. Lukiessani McLareniä olin aivan varma, että olen lukenut Sorrettujen pedagogiikan jo 1970-luvun lopulla, mutta tuo Freiren tunnetuin teos sai odottaa kuitenkin suomentamistaan aina vuoteen 2005 saakka (alkup. 1968). Silloin Vastapaino, tuo mainio kustannusliikkeiden avantgarde, sen julkaisi. Jostain Freire oli kuitenkin jo paljon aiemmin minuunkin tarttunut.

Kirjan anakronistiseksi kokemiseen vaikuttaa varmaan myös ero alkuperäisen julkaisemisen ja suomentamisen vuosissa. Vuonna 2000 saattoi ehkä vielä elätellä toivetta siitä, että maailma voisi olla jopa parempaan suuntaan menossa tai poliittisesti ohjattavissa. Nyt tällainen vaikutelma on aika etäinen. Vuonna 2001 aloitettu terrorismin vastainen sota vie meidät suoraan guevaralaisille taistelukentille, ja myös paikallista Freireä kaivattaisiin vaikka Afganistanissa tai Irakissa tai Jemenissä. Tai Yhdysvalloissa tai vaikkapa Suomessa, ei sen puoleen.

En muista näin pitkäveteistä ja samalla suorastaan palvovaa aloitusta lukeneeni missään kirjassa. Ensin Juha Suorannan esipuhe, jossa hän esittelee, tarpeellisesti, McLarenin. Suorantahan on Tampereen yliopiston aikuiskasvatuksen proffa ja ilmeisesti laskee McLarenin kavereidensa joukkoon. McLaren on jokusen kerran vieraillut Suomessakin kriittisen pedagogiikan tiimoilla. Sitten Joe L. Kincheloe esittele McLarenin pedagogisen vasemmiston hovikirjoittajaksi. Minun mielestäni minkäänlainen vasemmisto ei tarvitse minkäänlaisia hovikirjoittajia, siinä on rappion alku. Kolmannen esipuheen kirjoittaa Freiren leski Ana Maria Araújo Freire. Ja siten vielä, kuin parhaassa koulun kevätjuh- lassa, runotervehdys Peter McLarenille. Sen on kirjoittanut Luis Vitale ja suomentanut Suoranta. Tämän jälkeen, nyt ollaan sivulla 27, pääsee McLaren ääneen. Hän aloittaa toistakymmentä sivua pitkällä johdannolla, jota seuraa vielä pari sivua kiitoksia, ennen kuin sivulta 43 alkaa varsinainen teksti.

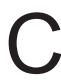

hen elämää ja ajatuksia käsitellään 150 sivun verran. Sille, joka johonkin mittaan tuntee marxismin perusteita ja ajattelutapaa ja sen lisäksi Chen elämäkertaa, tämä on turhaa luettavaa. Sen olisi myös voinut jossain esipuheessa todeta niin, ettei olisi monta kerta tarvinnut taistella itsensä kanssa, että heitänkö kirjan seinään. Toki joukossa on monia mielenkiintoisiakin ajatuksia, joista voisi kirjoittajan kanssa keskustella, mutta täältä saattaa olla hiukan pitkä matka. McLaren vertaa Chen viidakkovallankumouksen kokemuksia runsaimmin Meksikon zapatisteihin. Asian mielenkiintoisuutta lisää se, että EZLN on edelleen olemassa ja toimii erityisesti Chiapasissa, Meksikon etelässä, mistä se on liikkeelle lähtenytkin. Emiliano Zapatan, Che Guevaran ja subcomandante Marcosin muodostama ketju olisi mielenkiintoinen poliittisen ajattelun ja toiminnan analyysiharjoitus.

\section{$\mathrm{S}$} Sita Uusi sosialistinen toimija. Siitä runsaat 40 sivua eteenpäin on kunnon analyysiä nykymaailmasta, globaalista kapitalismista, demokratiasta ja kasvatuksesta. Ja aina tarpeen tullen palataan Chen ajatuksiin ja toimintaan. 
Joidenkin globalisaatiota koskevien analyy sinpätkien yhteydessä voi todeta, että suomalainen (tai eurooppalainen?) ja amerikkalainen ajattelu poikkeavat toisistaan. Mahtaako selittyä sillä, että kapitalismikriittinen amerikkalainen toimija on sen itsensä sisällä. Vallankin suomalainen voi (ainakin) yrittää tarkastella asioita ikään kuin ulkopuolelta. Vaikka meillä onkin Nokiamme ja Stora Ensomme (-mme?) jne.

Loppuaan kohti kirjan ensimmäinen osa, siis Chetä käsittelevä pääluku muuttuu peräti Chenekrologiksi. Tällainen suhtautumistapa suorastaan ärsyttää minua. En pidä siitä, että joku nostetaan kaapin päälle, melkein palvonnan kohteeksi. Näen siinä vaaran oikeaoppisuudesta, ja sellainen on aina omiaan tukahduttamaan itsenäisen, kriittisen ajattelun. Tämä sama kysymys on mielestäni esitettävä myös niille suomalaisille nuorille vasemmistolaisille, joille Chestä on tullut uusi idoli. Omasta puolestani voin sanoa, että mieluummin Che kuin Stalin, mutta ilmiö on perusluonteeltaan sama. Chen nostaminen suomalaiseen tai usa-laiseen poliittiseen symbolistoon on aika omituista, kun otetaan huomioon, millaisessa yhteiskunnallisessa todellisuudessa Che toimi. Ja epäonnistui kurjasti. Mitä mahtaa Bolivian Evo Morales ajatella Chestä?

\section{K} sittelevä pääluku tiivistää vajaaseen 50 sivuun Freiren pedagogisen ajattelun ytimen. Sorrettujen pedagogiikka nousee tässä yhteydessä keskeiseksi sisällöksi. Mutta samalla Freiren ajattelu kytketään, niin kuin pitääkin, kolonialismista vapautumisen ja anti-imperialistiseen taisteluun. Ajatteluviitteet alkavat Marxis- ta ja yltävät Maon ja Guevaran kautta Franz Fanoniin ja Amilcar Cabraliin. Tätä kautta Freire kytkeytyy vankasti mukaan nykyiseen globalisaation kritiikkiin. Kritiikki tässä ei ole eufemismi vastustamiselle niin kuin nykyisessä keskustelussa monissa asioissa vaikuttaa. Kritiikki on joidenkin asioiden tilojen perusteisiin menevää analyysiä, siitä oppimista ja valmiuksien kehittämistä asioiden muuttamiseen (paremmaksi, mitä se on? kyynikon huomautus). Siis ohjenuoraksi sopii Marxin 11. Feuerbach-teesi: Filosofit ovat kaikin ajoin vain pyrkineet selittämään maailmaa, kun tehtävänä on maailman muuttaminen. Olen ymmärtänyt, että tämä on myös Freiren pedagoginen ohjenuora.

Sivuseikka, mutta tässä luvussa (s. 222) McLaren kirjoittaa: "(Stanley) Aronowitz sijoittaa Freiren Rosa Luxemburgin ja muiden anarkistien traditioon, sillä Freirestä vallankumouksen on sytyttävä alhaalta käsin." En aiemmin ole kuullut Rosa Luxemburgia anarkistiksi kutsuttavan. Jos tuohon joukkoon pääsemiseksi riittää, että vaatii vallankumousta alhaalta käsin (kursivointi on alkuperäisessä), luulenpa, että suuri osa suomalaista vasemmistoa kuuluu samaan joukkoon. Kaikki eivät ehkä luonnehdintaa hyväksy. Eikä tavanomainen aatehistoria myöskään hyväksy anarkismille noin laihaa määritelmää.

\section{$\mathrm{K}_{\mathrm{i}}$} jan kolmannessa osassa on varsinainen pihvi, Aikamme vallankumouksen pedagogiikka. Tämän vajaa 30 -sivuisen esseen takia piti edellä olevat sivut kahlata läpi. Tämän olisi voinut julkaista myös erikseen tai kirjan aluksi, jonka jälkeen olisi voitu viitata laveastikin Che'hen ja
Freireen perustelujen esittämiseksi. Mutta kuinka vain! Tässä luvussa on kriittinen analyysi (ks. edellä) kapitalistisen järjestelmän pedagogisista haasteista, jotta se muuttuisi (muutettaisiin) vallankumoukselliseksi.

Tietenkin McLarenin analyysi pohjautuu amerikkalaiseen (erityisesti USA) koulujärjestelmään, ja me tietenkin pidämme omaamme parempana, mutta kuitenkin esimerkiksi ne pyrkimykset, joita opetusministeri Virkkunen on juuri lanseerannut korkeakoulujen sisäänpääsyn uudistamiseksi, herättävät ihan samanlaisia kysymyksiä. Lainaan McLarenin lainausta em. Aronowitzilta: "...koulutuksen korkein päämäärä ja ensisijainen tarkoitus on valmistaa opiskelijoita eri asteilla ottamaan paikkansa korporatiivisessa järjestyksessä.' (S. 248) "Korporatiivinen järjestys" tarkoittaa suomeksi "olla elinkeinoelämän palveluksessa". Tätähän meillä hallitus ja asiaan kuuluvat ministerit ovat kaiken aikaa toitottaneet. Totta kai minä taloustieteilijänä ymmärrän valtiontalouden kestävyysperustelut, mutta asiaan voidaan löytää muitakin näkökulmia, joita ei tässä voi käsitellä. Mutta äärimmäisen yksinkertaistaen: verotusta on kiristettävä, aloitetaan pääoma- ja tuloveroista.

Olennaista siis on erottaa ne pyrkimykset, joiden kautta opetus- ja sivistysjärjestelmät pyritään latistamaan pelkäksi elinkeinoelämää palvelevaksi koulutukseksi. Ja McLaren tiivistää hyvin (s. 268), mistä on kyse: 'Freireläinen ja guevaralainen pedagogiikka asettaa päämääräkseen tuotantovälineiden muuttamisen emansipaation välineiksi." Tosin sanoin sanottuna tämä tarkoittaa työn orjuudesta vapauttamista. Ja tämäkin asia voidaan 
sanoa vielä kolmannella, John Kenneth Galbraithin sanoilla: "Ihmisen vapauttaminen ruumiillisesta työstä on aivan eri asia kuin hänen vapauttamisensa älyllisestä ponnistelusta, mitä tehtävää pidän ennenaikaisena."

Kirjan oikolukemisessa ja joissakin suomennoksen kohdissa on toivomisen varaa, mutta eivät ne lukemista haittaa.

Lukemisen aikaan ilmestyi Hannu Juuson ja Tuukka Tomperin vieraskynäkirjoitus (HS 18.3.2010) lasten filosofoinnista kouluopetuksessa. Kirjoitus on sukua McLarenin ajattelulle. Tomperi onkin esitellyt suomek- si Freireä ja toimittanut Sorrettujen pedagogiikan suomennoksen yhdessä Suorannan kanssa. Freire elää!

\section{Aarni Tuominen}

\section{Sosiaalinen tila oppilaitoksen johtamisen haasteena}

Ahonen Helena (2008). Rehtoreiden kertoma johtajuus ja johtajaidentiteetti. Jyvaskyla Studies in Education, Psychology and Social Research 352. Jyväskylän yliopisto

\section{S} osiaalisen tilan vaikutukset johtajuuteen ja johtamisidentiteettiin ovat uudehkoja johtajuustutkimuksen teemoja. Tarkasteltavassa tutkimuksessa ne nousevat konkreettisesta oppilaitosjohtamisen arjesta. Aineistosta käy ilmi, kuinka oppilaitoksen rehtori tasapainoilee sekä asiantuntijayhteisön johtajana että työsuoritusten toteuttamisen esimiehenä. Koulun johtamisen arkeen kytkeytyvät vielä sen ulkopuoliset sidosryhmät, joihin johtajalla on erityinen suhteensa. Nämä ryhmät määrittelevät erityisesti johtajuuden autonomiaa, valtaa ja päätöksenteon valtuutta.

Helena Ahosen väitöskirja pureutuu johtajuuden ja johtajuusidentiteetin rakentumiseen. Tätä tutkimusteemaa hän lähestyy oppilaitosrehtoreiden kertomien konkreettisten johtajuustoimien ja -tilanteiden kautta. Onkin mielenkiintoista seurata, miten hän rakentaa johtajien kertoman toimintaympäristön analyysistä johtajien identiteetin muodostumisen aineksia.
Tarkasteltavassa väitöskirjassa käytetään siis sosiaalisen tilan käsitettä johtajuuden analysoinnin välineenä. Tämä monimutkainen fyysis-psyykkinen ja sosiaalinen kokonaisuus määrittää johtajuutta ja samalla johtajuus määrittää ja muovaa sitä. Koska johtaja on osa sosiaalista toimintatilaansa, ulottavat tämän tilan monenlaiset kytkökset lonkeronsa johtajan aina suhteelliseen autonomiaan, identiteettiin ja vuorovaikutukseen sekä valta-asemiin. Ahonen tuo nämä yhteydet väitöskirjassaan esiin.

Ahosen mukaan johtajan on kyettävä säätelemään johtajuuttaan sen mukaan, ketä sosiaalisessa tilassa toimii ja kuinka suuri on toimijoiden suhteellinen työhön liittyvä autonomia. Johtamisessa on tärkeää se sosiaalinen tila, jossa konkreettisia johtamistoimia tehdään. Usein johtajan omaamien koulun sisäisten suhteiden tila ei ole verrannollinen johtajan ja koulun ulkopuolisen suhteen kanssa. Ne eivät ole symmetrisiä eivätkä pysyviä, vaan alati muutoksessa. Siksi ne vaativat johtajuuden sosiaalisessa tilassa erityistä tarkkaavaisuutta.

Tutkimus nojaa diskurssianalyysiin, joka tarjoaa monitasoisen mahdollisuuden tekstien analysointiin ja tulkintaan. Ahonen ankkuroi itsensä kieleen todellisuuden välittäjänä. Rehtoreiden kertomusten analysointi vie tutkijan analysoimaan paitsi tekstiä, myös tekstien välejä, äännähdyksiä, taukoja jne. Tutkijan vastuu kasvaa suureksi, koska hän tulkitsee teoriakehityksestään myös sellaista, jota ei teksteissä varsinaisesti ole.

Tutkimus tarjoaa sosiaalisen tilan analyysin ohella tiiviin teoriakatsauksen oppilaitosjohtamisen tutkimuksesta. Katsaus osoittaa johtajuuden tutkimuksen monet virtaukset ja suunnat. Jotkut tutkijat lähestyvät teemaa strategisen johtajuuden kautta, jotkut muutosjohtajuuden tai johtajuuden sisältöanalyysin kautta. Käsiteltävä tutkimus tuo tähän mielenkiintoisen lisän, koska hän etsii johtajan identiteettiin vaikuttavia sosiaalisia ja vuorovaikutteisia tekijöitä. $\mathrm{Ne}$ kumpuavat rehtoreiden kirjoittamista teksteistä sekä haastatteluista. Aineiston koon huomioon ottaen, on tulosten tulkinnassa 